\title{
Patterns of nitrate transport in an agricultural watershed through consecutive dry years
}

\author{
shuai chen ${ }^{1}$ and Xiaohong RUAN ${ }^{1}$ \\ ${ }^{1}$ Nanjing University
}

May 13, 2020

\begin{abstract}
Recently, because of regional climate changes and human activities, the risk and intensity of droughts in the upper and middle Huaihe River Basin, China, have increased. These changes in rainfall may have, in turn, had an influence on the pathways of nitrate transport in this predominantly agricultural watershed. In this study, the characteristics of nitrate transport over consecutive dry years in this watershed were examined using records of streamflow and nitrate concentration data that spanned a period of 12 years (2007-2018) that included 3 consecutive dry years (2011-2013). The baseflow was separated from the streamflow using a digital filter method and the nitrate loads were estimated using a regression method. The annual discharge

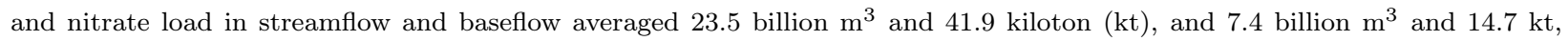
respectively. Baseflow contributed more to the total discharge and total nitrate load in the consecutive dry years (41.0\% of the total discharge and $56.2 \%$ of the total nitrate load) than in wet, normal, and single dry years. Averaged over the whole study period, the monthly baseflow nitrate index (BFNI) was higher than $50 \%$ in the dry season and lower than $30 \%$ in the flood season. Over the study period, the annual baseflow enrichment ratio (BER) ranged from 0.94 to 1.46 and averaged 1.13 , and was highest (1.46) in the consecutive dry years. The results suggest that nitrate was mainly transported to surface water via baseflow during dry conditions and that this process was particularly important during the consecutive dry years. Therefore, to protect surface water, measures should be urgently implemented to control nitrate transport in groundwater during consecutive dry years.
\end{abstract}

\section{Introduction}

Nitrogen (N) fertilizers, widely used in agricultural watersheds, have been identified as the main contributor to the increases in nitrate concentrations in groundwater and surface water (Coskun, Britto, Shi, \& Kronzucker, 2017; Worrall, Swank, \& Burt, 2003). Nitrate concentrations are generally much higher in groundwater below agricultural fields than in surface waters (Almasri \& Kaluarachchi, 2004; Gu, Ge, Chang, Luo, \& Chang, 2013; Reay, Gallagher, \& Simmons, 1992). This nitrate in groundwater may be primarily transferred to surface waters in baseflow conditions (He \& Lu, 2016; Schilling \& Zhang, 2004; Wriedt, Spindler, Neef, Meißner, \& Rode, 2007). It is therefore important to quantify the contribution of baseflow to total nitrate loads in streamflow so that techniques for reducing nitrate contamination can be developed (Ju \& Zhang, 2017).

In a changing climate, hydrological regimes are likely to become more extreme, with wet seasons becoming wetter and dry seasons becoming drier (Nyenje \& Batelaan, 2009). These changes may influence nitrate transport pathways; for example, during consecutive dry years, the contribution of groundwater to streamflow is likely to increase (Nathan \& McMahon, 1990; Price, 2011), thereby increasing the risk that more nitrate will be delivered to streams through baseflow, and possibly impacting on surface water quality. Many researchers have investigated how hydrological conditions influence nitrate transport, and have concluded that the nitrate 
loads from agricultural watersheds to surface water are low in low-flow periods, owing to the reduced runoff, but then increase after a drought ends (Schilling \& Zhang, 2004; Whitehead, Wilby, Battarbee, Kernan, \& Wade, 2009; Whitehead, Wilby, Butterfield, \& Wade, 2006). Few, however, have reported nitrate transport patterns during extremely long droughts that persist over many years, probably because of a lack of highquality water quality data for such periods. Because droughts of this nature occur very infrequently and are very unpredictable, it is difficult to set up a targeted sampling schedule to collect sufficient water quality data in these conditions (Sliva \& Williams, 2001). To support the development of effective policies to manage water quality, such as Total Maximum Daily Load (TMDL) programmes and Best Management Practices (BMPs), it is therefore important to quantify baseflow nitrate loads and their contribution to total nitrate loads in consecutive dry years (Guo, Markus, \& Demissie, 2002).

Thanks to the availability of water quality databases belonging to numerous governmental organizations and the availability of various estimation methods (Aulenbach, 2013; Cohn, 2005; Cohn, Delong, Gilroy, Hirsch, \& Wells, 1989; He, Hao, Wu, \& Lu, 2020; Verhoff, Yaksich, \& Melfi, 1980), the patterns of nitrate transport can be investigated. Even though the data held in these databases are usually collected in fixed sampling programs and so may be limited in their spatial and temporal resolution, these data can still support initial investigations of nitrate transport during consecutive dry years without requiring huge investments in time and resources (Sliva \& Williams, 2001). The methods used for estimating loads of chemical constituents are generally classified as averaging, ratio, and regression estimators (Guo et al., 2002). Regression methods assume that flow and concentration follow a bivariate lognormal distribution. In this study, we used the regression estimator LOAD ESTIMATOR (LOADEST), a FORTRAN program developed by Runkel, Crawford, and Cohn (2004), to calculate nitrate loads from routine monitoring data.

Agriculture, dominated by dry-land crops, is the most important activity in the Huaihe River Basin in eastern China. Because $\mathrm{N}$ fertilizers have been applied excessively in recent years, freshwater in the basin is severely polluted by nitrate from diffuse agricultural sources (Ju, Liu, \& Zhang, 2010). However, apart from Chen (2013) and Chen, Ruan, and Shan (2017), who estimated the nitrate loads in groundwater discharges using numerical models in a small sub-basin, few have reported the long-term nitrate loads in streamflow and quantified the contribution made by baseflow in this area. In addition, the runoff from the upper and middle reaches of the Huaihe River Basin has decreased significantly over the last 50 years, because of regional climate change and human activities (An \& Hao, 2017; Yan et al., 2014; Zhang, Shao, Xia, Bunn, \& Zuo, 2011), meaning that the risks and intensity of droughts have increased (Wang, Zhang, \& Singh, 2016), and consecutive dry years, as occurred from 2011 to 2013 (see supporting information), will probably occur more frequently in the future. The objectives of this study, therefore, were to (1) quantify the total nitrate loads exported from this agricultural watershed and quantify the contribution from baseflow, (2) evaluate the temporal patterns of nitrate loads in consecutive dry years, and (3) identify the main pathway of nitrate transport.

\section{Materials and methods}

\subsection{Study area and data collection}

The section of the Huaihe River examined in this study flows from west to east and drains a watershed of $121330 \mathrm{~km}^{2}$ above the Bengbu Hydrometric Station (Fig. 1). With elevations ranging from $2082 \mathrm{~m}$ in the northwest to $15 \mathrm{~m}$ in the east, the study area comprises hills and flatlands. The geology is dominated by Quaternary layers that mainly comprise fluvial and lacustrine loose sediments, and groundwater is stored in porous aquifers (Ge et al., 2006). The mean annual precipitation in the study area shows considerable spatial variation and ranges from $1400 \mathrm{~mm}$ in the south to $600 \mathrm{~mm}$ in the north, reflecting its location between the temperate sub-humid and subtropical humid monsoon climate zones. The flood season lasts from June to September and the dry season lasts from December to February. Rainfall accounts for $60 \%$ of the annual precipitation in the flood season and $8 \%$ in the dry season (Fig. 1d). As an important agricultural catchment, 
agricultural land accounts for $70.1 \%$ of the watershed area and annual $\mathrm{N}$ fertilizer application rates amount to about $600 \mathrm{~kg} \mathrm{~N} \mathrm{ha}^{-1} \mathrm{yr}^{-1}$ (Ju et al., 2010). According to the National Bureau of Statistics of China, the land use and $\mathrm{N}$-fertilizer application rates in the Huaihe River Basin did not change significantly in the past decade.

This study is based on daily stream discharge data collected from 2007 to 2018 at the Bengbu Station, which is operated by the Huaihe River Commission of the Water Resources Ministry of the P.R.C. Baseflow was extracted from streamflow using a digital filter method. Precipitation data were downloaded from the National Meteorological Information Center (http://data.cma.cn/site). Consecutive dry years were identified from annual runoff records of the study area (1956-2018) using frequency analysis. The results of this analysis showed that 2011-2014 were consecutive dry years, 2009 was an individual dry year, and the other years from 2007 to 2018 were normal or wet years (see supporting information).

A total of 128 samples of surface water were collected at the Bengbu Station from 2007 to 2018, either monthly or bimonthly, and analyzed for their nitrate concentrations. Groundwater samples were collected across the study area (Fig. 1c) once in flood season and non-flood season between 2011 and 2018 excluding 2013. Nitrate concentrations were determined in the laboratory by UV spectrophotometry and were reported as nitrogen (detection limit $=0.08 \mathrm{mg} / \mathrm{L}$ ).

\subsection{Methods}

To estimate the nitrate loads contributed by baseflow, the baseflow was extracted from the daily streamflow using the recursive digital filter method proposed by Eckhardt (2005). Assuming that the outflow from an aquifer is in linear proportion to its storage, the recursive digital filter method separates the streamflow into direct runoff and baseflow. It is stable and suitable for the low baseflow conditions in the study area. The filter is expressed as:

$\mathrm{b}_{\mathrm{k}}=\frac{\left(1-\mathrm{BFI}_{\max }\right) \alpha \mathrm{b}_{\mathrm{k}-1}+(1-\alpha) \mathrm{BFI}_{\max } \mathrm{y}_{\mathrm{k}}}{1-\alpha \mathrm{BFI}_{\max }}(1)$

Subject to $b_{k}$ [?] $y_{k}$ where $b$ is the baseflow, $k$ is the time step, $y$ is the total streamflow, and $B F I_{\max }$ and $a$ are the filter parameters.

Nitrate loads were estimated by developing a log-log regression model within LOADEST. It was assumed that the relationship between the logarithm of the constituent concentration and the logarithm of the discharge was approximately linear (Cohn, 1995). The simplest form of the linear model was described as:

$\ln (\mathrm{L})_{\text {est }}=\mathrm{a}_{0}+\sum_{\mathrm{j}=1}^{\mathrm{NV}} \mathrm{a}_{\mathrm{j}} \mathrm{X}_{\mathrm{j}}(2)$

Where $L$ was the instantaneous load, $\ln (L)$ est was the estimated natural $\operatorname{logarithm}$ of $L, a_{0}$, and $a_{j}$ were model coefficients, $N V$ was the number of explanatory variables, and $X_{j}$ was an explanatory variable that was a function of a data variable (streamflow or time, for example) which was thought to influence the instantaneous load (Runkel et al., 2004).

The 'baseflow enrichment ratio' (BER) was calculated in this study to identify the preferential pathways of nitrate transport. Schilling and Zhang (2004) proposed the term BER to describe the enrichment of baseflow water with nitrate. The BER is defined as

$B E R=B F N I / B F I(3)$

Where the BFNI (the baseflow nitrate index) is the ratio of the baseflow nitrate load to the streamflow nitrate load and BFI (the baseflow index) is the ratio of baseflow to streamflow. If nitrate essentially 'followed the water', then BFNI would be equal to BFI and the BER would equal 1. A BER value greater than 1 implies that nitrate is preferentially leached to groundwater and carried by baseflow to streams. 


\subsection{Model calibration and validation}

The filter parameter $B F I_{\max }$ was set as 0.8 in this study, which, according to Eckhardt (2005), is suitable for perennial streams with porous aquifers. The filter parameter awas determined by recession analysis (Eckhardt, 2008). The streamflow $y_{k}$ in a recession period of at least 5 days was taken into consideration; that is, it must be:

$y_{k-3}>y_{k-2}>y_{k-1}>y_{k}>y_{k+1}>y_{k+2}(4)$

$y_{k}$ and $y_{k+1}$ were assumed to obey the following relationship:

$y_{k+1}=a \psi_{\kappa}(5)$

A scatter plot of $y_{k+1}$ against $y_{k}$ was plotted in Figure 2, and the recession constant $a, 0.9982$ in this study, was the slope of the upper boundary line of the scatter plot.

Streamflow data and nitrate concentrations $(n=128)$ were input into LOADEST, and the nitrate loads estimated with this data set represented the nitrate loads exported from the watershed in streamflow (i.e., total nitrate loads). Baseflow and nitrate concentrations $(n=28)$ from days when baseflow accounted for between $90 \%$ and $100 \%$ of streamflow were used to estimate the nitrate loads contributed by baseflow (Schilling \& Zhang, 2004). The Adjusted Maximum Likelihood Estimation (AMLE) method was used to estimate regression parameters $\left(a_{j}\right)$ because the model residuals conformed to the three underlying assumptions about normal distribution, independence, and constant variance (Runkel et al., 2004). The calibration results of the two data sets (streamflow and baseflow) are shown in Figure 3. Scatter plots of the model residuals versus the estimated log load (Fig. 3a \& 3d) show that the positive and negative residuals were scattered without any clear patterns or trends. Therefore, the model residuals adhered to the independence and constant variance assumptions of the model fit. Normal probability plots for the model residuals are shown in Figures $3 \mathrm{~b}$ and $3 \mathrm{e}$, and the Probability Plot Correlation Coefficients (PPCC) for streamflow and baseflow were 0.992 and 0.982 , respectively. The relationships between the normal quantile and the residuals were linear, which suggest that the residuals followed a normal distribution (Helsel \& Hirsch, 2002), thereby satisfying another assumption of the model fit.

Three quantitative statistics, the Nash-Sutcliffe efficiency (NSE), percent bias (PBIAS), and the ratio of the root mean square error to the standard deviation of the measured data (RSR), were used to evaluate the accuracy of the simulated data relative to the measured data. As the values of NSE approach 1 and the RSR and PBAIS approach 0, the model simulation performance improves (Gupta, Sorooshian, \& Yapo, 1999; Nash \& Sutcliffe, 1970). Moriasi et al. (2007) recommended that a model simulation could be judged as satisfactory when the NSE $>0.50$ and the RSR [?] 0.70, and if the PBIAS for streamflow $< \pm 25 \%$ and PBIAS for nitrogen $< \pm 70 \%$. The NSE, RSR, and PBAIS of the model for estimating streamflow nitrate loads and baseflow nitrate loads were $0.773,0.477$, and $-1.701 \%$, and $0.729,0.521$, and $0.949 \%$, respectively. The accuracy of the model simulations obtained in this study was satisfactory and the scatter plots of the observed loads versus the estimated loads of streamflow and baseflow are shown in Figures 3c and 3f.

\section{Results and discussion}

\subsection{Nitrate concentrations}

The nitrate concentrations in surface water ranged from 0.31 to $4.45 \mathrm{mg} / \mathrm{L}$, averaged $2.05 \mathrm{mg} / \mathrm{L}$, and had a coefficient of variance $(\mathrm{CV})$ of 0.44 (Table 1). The nitrate concentrations in groundwater, at between $<0.08$ and $86.0 \mathrm{mg} / \mathrm{L}$, were higher than those in surface water and averaged $7.26 \mathrm{mg} / \mathrm{L}$. The results of a Seasonal Kendall test (Hirsch, Slack, \& Smith, 1982) showed that there was no temporal trend in the nitrate concentrations in surface water $(p>0.05)$. The surface water nitrate concentrations were generally highest when the streamflow was low (Fig. 4a). Mańczak and Florczyk (1971) summarized three types of relationships between concentration and flow for various water quality parameters, namely Type 1, a dilution 
curve; Type 2, a flow-driven release curve, and Type 3, dilution of point source effluent plus a flow-driven release curve (Fig. 4b). The discharges and nitrate concentrations observed at the Bengbu Station seemed to follow a Type 3 relationship (Fig. 4c); that is, the nitrate concentrations decreased as the streamflow increased during periods of low flow but increased as streamflow increased during periods of high flow.

Constituent loads are relatively constant in the Type 1 relationship because the main source is a point source discharge or the baseflow supplied by soil moisture or groundwater. For the Type 2 relationship, constituent loads can increase dramatically if the discharge increases because of storm flow scouring (Hirsch et al., 1982). The significant positive correlation between the observed daily nitrate load and discharge at the outlet suggests that the nitrate mainly derives from non-point sources in this watershed (Fig. 5a). The average nitrate concentration in groundwater $(7.26 \mathrm{mg} / \mathrm{L})$ was higher than that in surface water, and groundwater nitrate concentrations showed little temporal variability ( $p>0.05$, ANOVA, Table 1) (Fig. 5b). This implies that baseflow supplied by groundwater may be considered as a steady source of nitrate. In addition, as described later, the yearly and monthly baseflow nitrate loads were relatively constant (Fig. 6b; Fig. 7c). Therefore, the fact that the nitrate concentrations and discharges in this study approximated to a Type 3 relationship suggests that there is dilution of nitrate in baseflow during periods of low flow, and that large quantities of non-point source nitrate are released during high flow periods due to scouring of storm flow.

\subsection{Baseflow}

\section{Annual patterns}

The baseflow separated from the daily streamflow is shown in Figure 4a. During the study period, the annual streamflow varied from 8.5 to 38.9 billion $\mathrm{m}^{3}$ and averaged 23.5 billion $\mathrm{m}^{3}$, while the baseflow varied from 3.4 to 11.8 billion $\mathrm{m}^{3}$ and averaged 7.4 billion $\mathrm{m}^{3}$ (Table 2; Fig. 6a). There was less variation in the baseflow than the streamflow. During the consecutive dry years, the annual streamflow and baseflow averaged 9.7 and 4.0 billion $\mathrm{m}^{3}$, and were only $41.3 \%$ and $54.1 \%$ of the streamflow and baseflow averaged over the whole study period, respectively. Over the study period, the BFI varied from $25.5 \%$ to $43.6 \%$ and averaged $31.3 \%$. The BFI was $29.6 \%$ for 2009 , an individual dry year, and averaged $41.0 \%$ over the consecutive dry years, which suggests that the contribution of baseflow to streamflow increased during extremely long periods of drought.

\section{Seasonal patterns}

Averaged over the whole study period, the monthly streamflow increased from 0.84 billion $\mathrm{m}^{3}$ in January to a maximum of 4.92 billion $\mathrm{m}^{3}$ in July, and then gradually decreased to 1.04 billion $\mathrm{m}^{3}$ in December (Table 3; Fig. 7a). The baseflow followed a similar pattern to the streamflow, but the baseflow varied less and was generally lower than the streamflow. The baseflow peaked in September, reflecting the hysteresis in groundwater flow. The BFI was around $50 \%$ in the dry season and was between $14.9 \%$ and $32.7 \%$ in the flood season. This suggests that baseflow accounted for half of the streamflow in the dry season and less than one third of the streamflow in the flood season.

Averaged over the consecutive dry years, the monthly streamflow ranged from 0.34 to 1.94 billion $\mathrm{m}^{3}$ and the high values occurred in the flood season. The average monthly baseflow ranged from 0.13 to 0.50 billion $\mathrm{m}^{3}$ (Table 3; Fig. 7b). The baseflow was close to the streamflow during the non-flood season when the BFI was $>55 \%$. Both the monthly streamflow and baseflow in consecutive dry years were lower and less variable than when averaged over the whole study period, but the values of the BFI were higher in consecutive dry years, especially during the dry season, than in normal and wet years.

\subsection{Nitrate load}

\section{Annual patterns}


The annual nitrate loads discharged from the study area ranged from 17.1 kiloton (kt) in 2011 to $67.3 \mathrm{kt}$ in 2017 and averaged $41.9 \mathrm{kt}$ (Table 2). The nitrate loads transported in baseflow ranged from $8.1 \mathrm{kt}$ in 2011 to $20.3 \mathrm{kt}$ in 2017 and 2018 and averaged $14.7 \mathrm{kt}$. The nitrate loads often reached a maximum after high discharges (Fig. 6), and the nitrate loads in streamflow showed more temporal variation (C.V. $=0.43$ ) than those in baseflow $(\mathrm{C} . \mathrm{V} .=0.27)$. The BFNI, which ranged from $27.0 \%$ in 2016 to $63.4 \%$ in 2012 and averaged $35.2 \%$, showed high temporal variability. During the consecutive dry years, the mean annual nitrate loads in streamflow and baseflow were 19.0 and $10.7 \mathrm{kt}$, respectively, and the BFNI averaged $56.2 \%$. It suggests that more nitrate was transported in baseflow than in surface runoff through consecutive dry years. The BFNI, at $17.3 \%$ higher, was greater over the 3 dry years than it was in 2009 , the single dry year $(38.9 \%)$, and was $21.0 \%$ higher than the average over the study period $(35.2 \%)$.

Compared to the whole study period, the average annual nitrate loads in streamflow and baseflow were relatively lower in the consecutive dry years, but the average BFI and BFNI in the consecutive dry years were $9.7 \%$ and $21.0 \%$ higher, respectively, than those averaged over the whole study period; this indicated that the percentage of discharge and nitrate loads contributed by groundwater were higher at this time, which could lead to high nitrate concentrations in surface water and associated environmental problems. This means that to protect the surface water quality in consecutive dry years, the nitrate concentrations in groundwater need to be controlled.

\section{Seasonal patterns}

Averaged over the whole study period (2007-2018), the monthly streamflow nitrate load (2.58-6.73 kt) followed a similar seasonal pattern as the streamflow discharge (Table 3; Fig. 7a \& 7c). The monthly baseflow nitrate loads in the non-flood season ranged from 0.83 to $1.72 \mathrm{kt}$, and were generally larger than those in the flood season, when they ranged from 0.94 to $1.06 \mathrm{kt}$. The monthly BFNI ranged from $16.8 \%$ to $56.4 \%$, and it was higher than $50 \%$ in the dry season and lower than $30 \%$ in the flood season. The seasonal variations in the BFNI indicate that more nitrate was delivered in baseflow than in surface runoff during the dry season and more nitrate was delivered in surface runoff than in baseflow during the flood season.

From 2011 to 2013, when it was continuously dry, the monthly streamflow nitrate loads in winter (JanMar) and summer (Jul-Sep) followed a similar pattern and, ranging from 1.7 to $2.5 \mathrm{kt}$, were higher than in the other seasons. These higher loads reflect the relatively high nitrate concentrations and low discharge in winter and the relatively high discharge and low nitrate concentrations in summer (Table 3; Fig. 7d). During the non-flood season, the BFNI was between $64.4 \%$ and $83.8 \%$ and the nitrate loads in baseflow and streamflow were similar, which suggests that the nitrate in surface waters was mainly delivered from groundwater via baseflow in dry conditions.

\subsection{Baseflow enrichment ratio}

The annual BER ranged from 0.94 to 1.46 and averaged 1.13; the BER values were higher in dry years than in normal and wet years (Table 2; Fig. 8a). There was a strong negative correlation between the annual precipitation and the BER (Fig. 8b), which indicates that baseflow was the preferential pathway for nitrate transport in dry years. The average BER of 1.13 suggests that, in this study area, nitrate was preferentially leached to groundwater and then discharged to streams through baseflow over long time periods. Studies of other agricultural watersheds have reported mean BER values greater than 1; for example, BER values of 1.14 and 1.23 were reported in the Walnut Creek (Schilling, 2002) and Raccoon River (Schilling \& Zhang, 2004) watersheds in the US, respectively. Together, these results suggest that nitrate is primarily transported to surface water through groundwater flow in agricultural areas (Jordan, Correll, \& Weller, 1997).

Averaged over 2007-2018, the monthly BER was greater than 1 from January to June and lower than 1 from August to November (Table 3; Fig. 8c). The monthly BER and the monthly precipitation were not significantly correlated $(\mathrm{p}>0.05)$ (Fig. $8 \mathrm{~d})$. Over the long-term, nitrate is preferentially transported in baseflow during winter and spring and is preferentially transported in surface runoff during late summer and 
autumn. The depletion of nitrate in baseflow from August to November coincides with the growing season, probably because of crop uptake (Schilling \& Zhang, 2004).

From 2011 to 2013, the average monthly BER was greater than 1 for all months and reached a maximum value of 1.39 in July and August. This infers that nitrate was preferentially transported in baseflow throughout the consecutive dry years. The monthly BER and monthly precipitation were strongly and positively correlated $(\mathrm{p}<0.05)$ during the consecutive dry years (Fig. 8d). Ju et al. (2010) reported that around $27 \%$ of the fertilizer $\mathrm{N}$ applied to land accumulated in the soils of the study area, and that this percentage was higher in consecutive dry years, when there was less dilution. Moreover, there is limited denitrification and immobilization in the lightly textured soil in this area, which may mean that nitrate leaching increases during intensive rainfall events in summer (Huang et al., 2014; Huang, Ju, \& Yang, 2017; Ju \& Zhang, 2017). Therefore, the significant positive correlation between the monthly BER and monthly precipitation, during the consecutive dry years, may reflect the fact that large amounts of nitrate accumulate in soils during the dry season and large amounts of nitrate are leached to groundwater during the flood season.

It was also interesting to find that the relationships between the monthly BER and monthly precipitation and the annual BER and annual precipitation were quite different (Fig. 8b \& 8d). This indicates that the correlations between hydrogeochemical variables should not be arbitrarily applied across different time scales without a thorough understanding of the ongoing physical, chemical, and biological processes.

\section{Conclusions}

In this study, nitrate loads were quantified in streamflow and baseflow in an agricultural watershed from 2007 to 2018, and then were examined in detail to identify patterns in the nitrate loads through consecutive dry years (2011-2013) and the main nitrate transport pathway. The annual streamflow and baseflow discharges averaged 23.5 and 7.4 billion $\mathrm{m}^{3}$, respectively. The BFI averaged $31.3 \%$ over the whole study period and averaged $41.0 \%$ over the consecutive dry years, which suggests that the contribution of baseflow to streamflow increased during extended drought periods. The annual nitrate loads in streamflow and baseflow averaged 41.9 and $14.7 \mathrm{kt}$, respectively. Baseflow, represented by the BFNI, accounted for $56.2 \%$ of the total nitrate loads in the consecutive dry years, and was $17.3 \%$ higher in the consecutive dry years than in the individual dry year (2009) and $21.0 \%$ higher than the mean annual value. It suggests that baseflow was the predominant delivery mechanism for nitrate loading to surface water in consecutive dry years. Averaged over the whole study period, the monthly BFNI was higher than $50 \%$ in the dry season and lower than $30 \%$ in the flood season, indicating that a larger portion of nitrate loads was delivered by baseflow in the dry season, as opposite to the flood season. The annual BER ranged from 0.94 to 1.46, averaged 1.13, and was highest in the consecutive dry years. From 2007 to 2018, the average monthly BER was greater than 1 in winter and spring but lower than 1 in late summer and autumn. The monthly BER through the consecutive dry years was always greater than 1 and reached a maximum of 1.39 in the flood season. Compared to the normal and wet years, the higher BER values in dry years suggest that nitrate was preferentially leached to groundwater, and then transported to streams through baseflow in drier conditions.

The results from this study provide insights into the patterns of nitrate transport under different hydrological conditions. We have demonstrated that baseflow was the primary pathway for nitrate transport in this agricultural area, and that the amount of nitrate transported to surface water by baseflow was greater than that transported by surface runoff in consecutive dry years. Therefore, to protect surface water quality through dry periods that extend over consecutive years, high priority should be given to groundwater nitrate control and management in the Huaihe River Basin. Furthermore, data collected at high spatial and temporal frequencies using near-continuous monitoring techniques (Blaen et al., 2016; Ockenden et al., 2016; van Geer, Kronvang, \& Broers, 2016) should be analyzed to give an improved understanding of the spatial and temporal variations in nitrate loads. 


\section{References}

Almasri, M. N., \& Kaluarachchi, J. J. (2004). Assessment and management of long-term nitrate pollution of ground water in agriculture-dominated watersheds. Journal of Hydrology, 295 (1-4), 225-245.

An, G., \& Hao, Z. (2017). Variation of Precipitation and Streamflow in the Upper and Middle Huaihe River Basin, China, from 1959-2009. Journal of Coastal Research, 80 (sp1), 69-79.

Aulenbach, B. T. (2013). Improving regression-model-based streamwater constituent load estimates derived from serially correlated data. Journal of Hydrology, 503 , 55-66.

Blaen, P. J., Khamis, K., Lloyd, C. E. M., Bradley, C., Hannah, D., \& Krause, S. (2016). Real-time monitoring of nutrients and dissolved organic matter in rivers: Capturing event dynamics, technological opportunities and future directions.Science of The Total Environment, 569-570 , 647-660.

Chen, L. (2013). Modeling of the water flow and nitrate transport in the shallow aquifer of the Shaying River Basin and its contribution to river pollution. (Master), Nanjing University, Nanjing. (in Chinese)

Chen, Z., Ruan, X., \& Shan, N. (2017). Modeling of nitrate flux between groundwater and surface water based on a coupled model in Shaying River Basin. Journal of Nanjing University (Natural Science), 53 (5), 860-870. (in Chinese)

Cohn, T. A. (1995). Recent advances in statistical methods for the estimation of sediment and nutrient transport in rivers. Reviews of Geophysics, 33 (S2), 1117-1123.

Cohn, T. A. (2005). Estimating contaminant loads in rivers: An application of adjusted maximum likelihood to type 1 censored data. Water Resources Research, 41 . W07003, doi:10.1029/2004WR003833.

Cohn, T. A., Delong, L. L., Gilroy, E. J., Hirsch, R. M., \& Wells, D. K. (1989). Estimating constituent loads. Water Resources Research, 25 (5), 937-942.

Coskun, D., Britto, D. T., Shi, W. M., \& Kronzucker, H. J. (2017). Nitrogen transformations in modern agriculture and the role of biological nitrification inhibition.Nature Plants, 3 (6), 10.

Eckhardt, K. (2005). How to construct recursive digital filters for baseflow separation. Hydrological Processes, 19 (2), 507-515.

Eckhardt, K. (2008). A comparison of baseflow indices, which were calculated with seven different baseflow separation methods. Journal of Hydrology, 352 (1-2), 168-173.

Ge, W., Ye, N., Gong, J., Yu, J., Zuo, Z., Yang, Z., et al. (2006). The quaternary aquifer division and character analysis of plain in Huaihe River basin. Resources Survey 63 Environment, 27 (4), 268-276. (in Chinese)

Gu, B., Ge, Y., Chang, S. X., Luo, W., \& Chang, J. (2013). Nitrate in groundwater of China: Sources and driving forces. Global Environmental Change, 23 (5), 1112-1121.

Guo, Y., Markus, M., \& Demissie, M. (2002). Uncertainty of nitrate-N load computations for agricultural watersheds. Water Resources Research, 38 (10), 3-1 - 3-12.

Gupta, H. V., Sorooshian, S., \& Yapo, P. O. (1999). Status of Automatic Calibration for Hydrologic Models: Comparison with Multilevel Expert Calibration. Journal of Hydrologic Engineering, 4 (2), 135-143.

He, S., Hao, Y., Wu, J., \& Lu, J. (2020). Estimation of baseflow nitrate loads by a recursive tracing source algorithm in a rainy agricultural watershed. Hydrological Processes, 34 (2), 441-454.

He, S., \& Lu, J. (2016). Contribution of baseflow nitrate export to non-point source pollution.Science China Earth Sciences, 59 (10), 1912-1929. 
Helsel, D. R., \& Hirsch, R. M. (2002). Statistical methods in water resources : U.S. Geological Survey Techniques of WaterResources Investigations.

Hirsch, R. M., Slack, J. R., \& Smith, R. A. (1982). Techniques of Trend Analysis for Monthly Water Quality Data. Water Resources Research, 18 (1), 107-121.

Huang, T., Gao, B., Hu, X., Lu, X., Well, R., Christie, P., ... Ju, X. (2015). Ammonia-oxidation as an engine to generate nitrous oxide in an intensively managed calcareous Fluvo-aquic soil. Scientific Reports, 4 , 3950. doi:10.1038/srep03950.

Huang, T., Ju, X., \& Yang, H. (2017). Nitrate leaching in a winter wheat-summer maize rotation on a calcareous soil as affected by nitrogen and straw management.Scientific Reports, 7 , 42247. doi:10.1038/srep42247.

Johnson, A. H. (1979). Estimating solute transport in streams from grab samples. Water Resources Research, 15 (5), 1224-1228.

Jordan, T. E., Correll, D. L., \& Weller, D. E. (1997). Relating nutrient discharges from watersheds to land use and streamflow variability. Water Resources Research, 33 (11), 2579-2590.

Ju, X., Liu, X., \& Zhang, L. (2010).Nitrogen cycling and ecoenvironment effect of winter wheat-summer maize rotation in North China Plain. In: Fundamental Research on Fate and Efficient Use of Nitrogen Fertilizer in Main Agroecosystems. Science Press, China. pp. 55-106. (in Chinese)

Ju, X., \& Zhang, C. (2017). Nitrogen cycling and environmental impacts in upland agricultural soils in North China: A review. Journal of Integrative Agriculture, 16 (12), 2848-2862.

Mańczak, H., \& Florczyk, H. (1971). Interpretation of results from the studies of pollution of surface flowing waters. Water Research, 5 (8), 575-584.

Moriasi, D. N., Arnold, J. G., Van Liew, M. W., Bingner, R. L., Harmel, R. D., \& Veith, T. L. (2007). Model Evaluation Guidelines for Systematic Quantification of Accuracy in Watershed Simulations. Transactions of the ASABE, 50 (3), 885-900.

Nash, J. E., \& Sutcliffe, J. V. (1970). River flow forecasting through conceptual models part I - A discussion of principles. Journal of Hydrology, 10 (3), 282-290.

Nathan, R. J., \& McMahon, T. A. (1990). Evaluation of automated techniques for base flow and recession analyses. Water Resources Research, 26 (7), 1465-1473.

Nyenje, P. M., \& Batelaan, O. (2009). Estimating the effects of climate change on groundwater recharge and baseflow in the upper Ssezibwa catchment, Uganda. Hydrological Sciences Journal, 54 (4), 713-726.

Ockenden, M. C., Deasy, C. E., Benskin, C. M. H., Beven, K. J., Burke, S., Collins, A. L., .. Haygarth, P. M. (2016). Changing climate and nutrient transfers: Evidence from high temporal resolution concentration-flow dynamics in headwater catchments. Science of The Total Environment, 548-549, 325-339.

Price, K. (2011). Effects of watershed topography, soils, land use, and climate on baseflow hydrology in humid regions: A review. Progress in Physical Geography: Earth and Environment, 35 (4), 465-492.

Reay, W. G., Gallagher, D. L., \& Simmons, G. M. (1992). Groundwater Discharge and Its Impact on Surface Water Quality in a Chesapeake Bay Inlet. Journal of the American Water Resources Association, 28 (6), 1121-1134.

Runkel, R. L., Crawford, C. G., \& Cohn, T. A. (2004). Load estimator (LOADEST)-A FORTRAN program for estimating constituent loads in streams and rivers. U.S.Geological Survey Techniques and Methods, Book 4, 69p (Chapter A5).

Schilling, K. E. (2002). Chemical Transport From Paired Agricultural and Restored Prairie Watersheds. Journal of Environmental Quality, 31 (4), 1184-1193. 
Schilling, K. E., \& Zhang, Y. K. (2004). Baseflow contribution to nitrate-nitrogen export from a large, agricultural watershed, USA. Journal of Hydrology, 295 (1-4), 305-316.

Sliva, L., \& Williams, D. D. (2001). Buffer zone versus whole catchment approaches to studying land use impact on river water quality. Water Research, 35 (14), 3462-3472.

van Geer, F. C., Kronvang, B., \& Broers, H. P. (2016). High-resolution monitoring of nutrients in groundwater and surface waters: process understanding, quantification of loads and concentrations, and management applications. Hydrology and Earth System Science, 20 (9), 3619-3629.

Verhoff, F. H., Yaksich, S. M., \& Melfi, D. A. (1980). River nutrient and chemical-transport estimation.Journal of the Environmental Engineering Division-Asce, 106 (3), 591-608.

Wang, Y., Zhang, Q., \& Singh, V. P. (2016). Spatiotemporal patterns of precipitation regimes in the Huai River basin, China, and possible relations with ENSO events. Natural Hazards, 82 (3), 2167-2185.

Whitehead, P. G., Wilby, R. L., Battarbee, R. W., Kernan, M., \& Wade, A. J. (2009). A review of the potential impacts of climate change on surface water quality.Hydrological Sciences Journal, 54 (1), 101-123.

Whitehead, P. G., Wilby, R. L., Butterfield, D., \& Wade, A. J. (2006). Impacts of climate change on instream nitrogen in a lowland chalk stream: An appraisal of adaptation strategies. Science of The Total Environment, 365 (1-3), 260-273.

Worrall, F., Swank, W. T., \& Burt, T. P. (2003). Changes in stream nitrate concentrations due to land management practices, ecological succession, and climate: Developing a systems approach to integrated catchment response. Water Resources Research, 39 (7). doi:10.1029/2000WR000130

Wriedt, G., Spindler, J., Neef, T., Meißner, R., \& Rode, M. (2007). Groundwater dynamics and channel activity as major controls of in-stream nitrate concentrations in a lowland catchment system? Journal of Hydrology, 343 (3), 154-168.

Yan, D., Han, D., Wang, G., Yuan, Y., Hu, Y., \& Fang, H. (2014). The evolution analysis of flood and drought in Huai River Basin of China based on monthly precipitation characteristics. Natural Hazards, 73 (2), 849-858.

Zhang, Y., Shao, Q., Xia, J., Bunn, S., \& Zuo, Q. (2011). Changes of flow regime and precipitation in Huai River Basin in the last half century. Hydrological Processes, 25 (2), 246-257.

Table 1

Summary information about surface water nitrate concentrations at the Bengbu Station and groundwater nitrate concentrations across the study area.

\begin{tabular}{|c|c|c|c|c|c|c|}
\hline $\begin{array}{l}\text { Nitrate } \\
\text { concentration }\end{array}$ & $\operatorname{Min}(\mathrm{mg} / \mathrm{L})$ & Mean $(\mathrm{mg} / \mathrm{L})$ & $\operatorname{Max}(\mathrm{mg} / \mathrm{L})$ & $\begin{array}{l}\text { Standard } \\
\text { deviation }\end{array}$ & $\begin{array}{l}\text { Coefficient of } \\
\text { Variance } \\
\text { (C.V.) }\end{array}$ & $p$ value \\
\hline $\begin{array}{l}\text { Surface } \\
\text { water }\end{array}$ & 0.31 & 2.05 & 4.45 & 0.91 & 0.44 & $0.641^{*}$ \\
\hline Groundwater & $<0.08$ & 7.26 & 86.0 & 12.3 & 1.69 & $0.775^{* *}$ \\
\hline
\end{tabular}

* Seasonal Kendall test

** Analysis of variance

Table 2

Annual streamflow, baseflow, baseflow index (BFI), streamflow nitrate load, baseflow nitrate load, baseflow nitrate index (BFNI), and baseflow enrichment ratio (BER). 


\begin{tabular}{|c|c|c|c|c|c|c|c|}
\hline Year & $\begin{array}{l}\text { Streamflow } \\
\left(\text { billion } \mathrm{m}^{3} \text { ) }\right.\end{array}$ & $\begin{array}{l}\text { Baseflow } \\
\text { (billion } \mathrm{m}^{3} \text { ) }\end{array}$ & BFI (\%) & $\begin{array}{l}\text { Streamflow } \\
\text { nitrate load } \\
\text { (kiloton) }\end{array}$ & $\begin{array}{l}\text { Baseflow } \\
\text { nitrate load } \\
\text { (kiloton) }\end{array}$ & BFNI (\%) & BER \\
\hline 2007 & 38.9 & 11.8 & 30.3 & 53.6 & 15.3 & 28.6 & 0.94 \\
\hline 2008 & 28.1 & 9.0 & 32.0 & 43.5 & 16.4 & 37.6 & 1.17 \\
\hline 2009 & 15.6 & 4.6 & 29.6 & 26.7 & 10.4 & 38.9 & 1.32 \\
\hline 2010 & 32.3 & 9.2 & 28.4 & 54.8 & 18.6 & 34.0 & 1.20 \\
\hline 2011 & 9.3 & 3.6 & 38.6 & 17.1 & 8.1 & 47.5 & 1.23 \\
\hline 2012 & 11.1 & 4.8 & 43.6 & 21.3 & 13.5 & 63.4 & 1.46 \\
\hline 2013 & 8.5 & 3.4 & 40.4 & 18.7 & 10.5 & 56.0 & 1.39 \\
\hline 2014 & 18.3 & 5.9 & 32.2 & 32.9 & 12.3 & 37.3 & 1.16 \\
\hline 2015 & 26.2 & 8.3 & 31.7 & 48.3 & 17.1 & 35.3 & 1.11 \\
\hline 2016 & 27.6 & 7.0 & 25.5 & 52.0 & 14.1 & 27.0 & 1.06 \\
\hline 2017 & 36.3 & 11.3 & 31.2 & 67.3 & 20.3 & 30.2 & 0.97 \\
\hline 2018 & 30.0 & 9.2 & 30.7 & 66.4 & 20.3 & 30.6 & 1.00 \\
\hline $\begin{array}{l}\text { Average } \\
\text { over the } \\
\text { consecu- } \\
\text { tive dry } \\
\text { years } \\
(2011- \\
2013)\end{array}$ & 9.7 & 4.0 & 41.0 & 19.0 & 10.7 & 56.2 & 1.37 \\
\hline $\begin{array}{l}\text { Average } \\
\text { over the } \\
\text { study } \\
\text { period } \\
(2007- \\
2018)\end{array}$ & 23.5 & 7.4 & 31.3 & 41.9 & 14.7 & 35.2 & 1.13 \\
\hline
\end{tabular}

Table 3

Monthly streamflow, baseflow, baseflow index (BFI), streamflow nitrate load, baseflow nitrate load, baseflow nitrate index (BFNI), and baseflow enrichment ratio (BER) averaged over 2007-2018 and 2011-2013.

\begin{tabular}{|c|c|c|c|c|c|c|c|c|}
\hline $\begin{array}{l}\text { Time } \\
\text { span }\end{array}$ & Month & $\begin{array}{l}\text { Monthly } \\
\text { Stream- } \\
\text { flow } \\
(\text { Billion } \\
\left.\mathrm{m}^{3}\right)\end{array}$ & $\begin{array}{l}\text { Monthly } \\
\text { Base- } \\
\text { flow } \\
(\text { Billion } \\
\left.\mathrm{m}^{3}\right)\end{array}$ & BFI & $\begin{array}{l}\text { Monthly } \\
\text { Stream- } \\
\text { flow } \\
\text { nitrate } \\
\text { load } \\
\text { (kiloton) }\end{array}$ & $\begin{array}{l}\text { Monthly } \\
\text { Base- } \\
\text { flow } \\
\text { nitrate } \\
\text { load } \\
\text { (kiloton) }\end{array}$ & BFNI & BER \\
\hline \multirow[t]{10}{*}{$2007-2018$} & Jan & 0.84 & 0.44 & 53.1 & 2.59 & 1.46 & 56.4 & 1.06 \\
\hline & Feb & 0.74 & 0.38 & 51.1 & 2.61 & 1.47 & 56.1 & 1.10 \\
\hline & Mar & 1.25 & 0.44 & 35.5 & 4.14 & 1.72 & 41.5 & 1.17 \\
\hline & Apr & 1.37 & 0.49 & 35.8 & 3.91 & 1.66 & 42.4 & 1.19 \\
\hline & May & 1.35 & 0.51 & 37.6 & 3.11 & 1.35 & 43.4 & 1.15 \\
\hline & Jun & 1.57 & 0.40 & 25.2 & 2.83 & 0.83 & 29.5 & 1.17 \\
\hline & $\mathrm{Jul}$ & 4.92 & 0.73 & 14.9 & 6.37 & 0.94 & 14.8 & 0.99 \\
\hline & Aug & 3.66 & 0.93 & 25.3 & 4.27 & 0.91 & 21.3 & 0.84 \\
\hline & Sep & 3.20 & 1.05 & 32.7 & 3.84 & 1.06 & 27.7 & 0.85 \\
\hline & Oct & 2.11 & 0.85 & 40.4 & 3.02 & 1.05 & 34.8 & 0.86 \\
\hline
\end{tabular}




\begin{tabular}{|c|c|c|c|c|c|c|c|c|}
\hline $\begin{array}{l}\text { Time } \\
\text { span }\end{array}$ & Month & $\begin{array}{l}\text { Monthly } \\
\text { Stream- } \\
\text { flow } \\
(\text { Billion } \\
\left.\mathrm{m}^{3}\right)\end{array}$ & $\begin{array}{l}\text { Monthly } \\
\text { Base- } \\
\text { flow } \\
(\text { Billion } \\
\left.\mathrm{m}^{3}\right)\end{array}$ & BFI & $\begin{array}{l}\text { Monthly } \\
\text { Stream- } \\
\text { flow } \\
\text { nitrate } \\
\text { load } \\
\text { (kiloton) }\end{array}$ & $\begin{array}{l}\text { Monthly } \\
\text { Base- } \\
\text { flow } \\
\text { nitrate } \\
\text { load } \\
\text { (kiloton) }\end{array}$ & BFNI & BER \\
\hline \multirow{14}{*}{$2011-2013$} & Nov & 1.46 & 0.63 & 43.1 & 2.75 & 1.04 & 37.9 & 0.88 \\
\hline & Dec & 1.04 & 0.51 & 49.6 & 2.58 & 1.29 & 50.1 & 1.01 \\
\hline & Jan & 0.56 & 0.39 & 69.2 & 1.81 & 1.52 & 83.8 & 1.21 \\
\hline & Feb & 0.54 & 0.32 & 59.9 & 1.91 & 1.28 & 67.3 & 1.12 \\
\hline & Mar & 0.64 & 0.36 & 55.7 & 2.25 & 1.45 & 64.4 & 1.16 \\
\hline & Apr & 0.44 & 0.32 & 72.2 & 1.40 & 1.21 & 86.1 & 1.19 \\
\hline & May & 0.34 & 0.21 & 61.8 & 0.85 & 0.64 & 75.6 & 1.22 \\
\hline & Jun & 0.35 & 0.13 & 37.7 & 0.67 & 0.33 & 49.3 & 1.31 \\
\hline & Jul & 1.18 & 0.20 & 16.9 & 1.74 & 0.41 & 23.4 & 1.39 \\
\hline & Aug & 1.67 & 0.22 & 13.4 & 2.05 & 0.38 & 18.7 & 1.39 \\
\hline & Sep & 1.94 & 0.50 & 25.9 & 2.44 & 0.75 & 30.7 & 1.19 \\
\hline & Oct & 0.73 & 0.49 & 67.7 & 1.13 & 0.85 & 75.8 & 1.12 \\
\hline & Nov & 0.64 & 0.42 & 65.7 & 1.27 & 0.91 & 72.1 & 1.10 \\
\hline & Dec & 0.65 & 0.41 & 63.3 & 1.62 & 1.13 & 69.5 & 1.10 \\
\hline
\end{tabular}

Fig. 1 (a) \& (b) Location of the study area, (c) sampling sites and the land use types, and (d) seasonal variations in the areal precipitation averaged for 1956-2018. The Bengbu Hydrometric Station is located at the drainage outlet of the study area.

Fig. 2 Streamflow $y_{k+1}$ plotted against $y_{k}$ during recession periods at the Bengbu Station, Huaihe River. The dashed line is the line through origin with slope $a=0.9982$.

Fig. 3 (a) \& (d) model residuals $[\ln (L)-\ln (L)$ est] versus estimates of the log load; (b) \& (e) normal probability plots for the model residuals $(\mathrm{PPCC}=$ Probability Plot Correlation Coefficient); (c) \& (f) scatter plots of the observed load versus the estimated load.

Fig. 4 (a) Daily discharges and nitrate concentrations in streamflow and baseflow at the Bengbu Station from 2007 to 2018, and (b) typical relationships between concentration and flow (redrawn from Johnson (1979)). Type 1 is a dilution curve, Type 2 shows a flow-driven release curve, and Type 3 shows dilution of point source effluent plus flow-driven release curve. (c) Scatter plot of the nitrate concentration versus discharge observed at the Bengbu Station from 2007 to 2018.

Fig. 5 (a) Correlation between the daily nitrate load and daily discharge observed in streamflow and (b) boxplot of the groundwater nitrate concentrations monitored across the watershed above the Bengbu Station from 2011 to 2018 excluding 2013.

Fig. 6 (a) Annual discharge of streamflow and baseflow and annual BFI and (b) annual nitrate loads in streamflow and baseflow and annual BFNI.

Fig. 7 Monthly streamflow, baseflow, and BFI averaged over (a) 2007-2018 and (b) 2011-2013; monthly streamflow nitrate load, baseflow nitrate load, and BFNI averaged over (c) 2007-2018 and (d) 2011-2013.

Fig. 8 (a) Annual variations in the BER, (b) scatter plot of the BER versus annual precipitation, (c) seasonal variations in the BER for 2007-2018 and 2011-2013, and (d) scatter plots of the monthly mean BER versus the monthly mean precipitation for 2007-2018 and 2011-2013. 

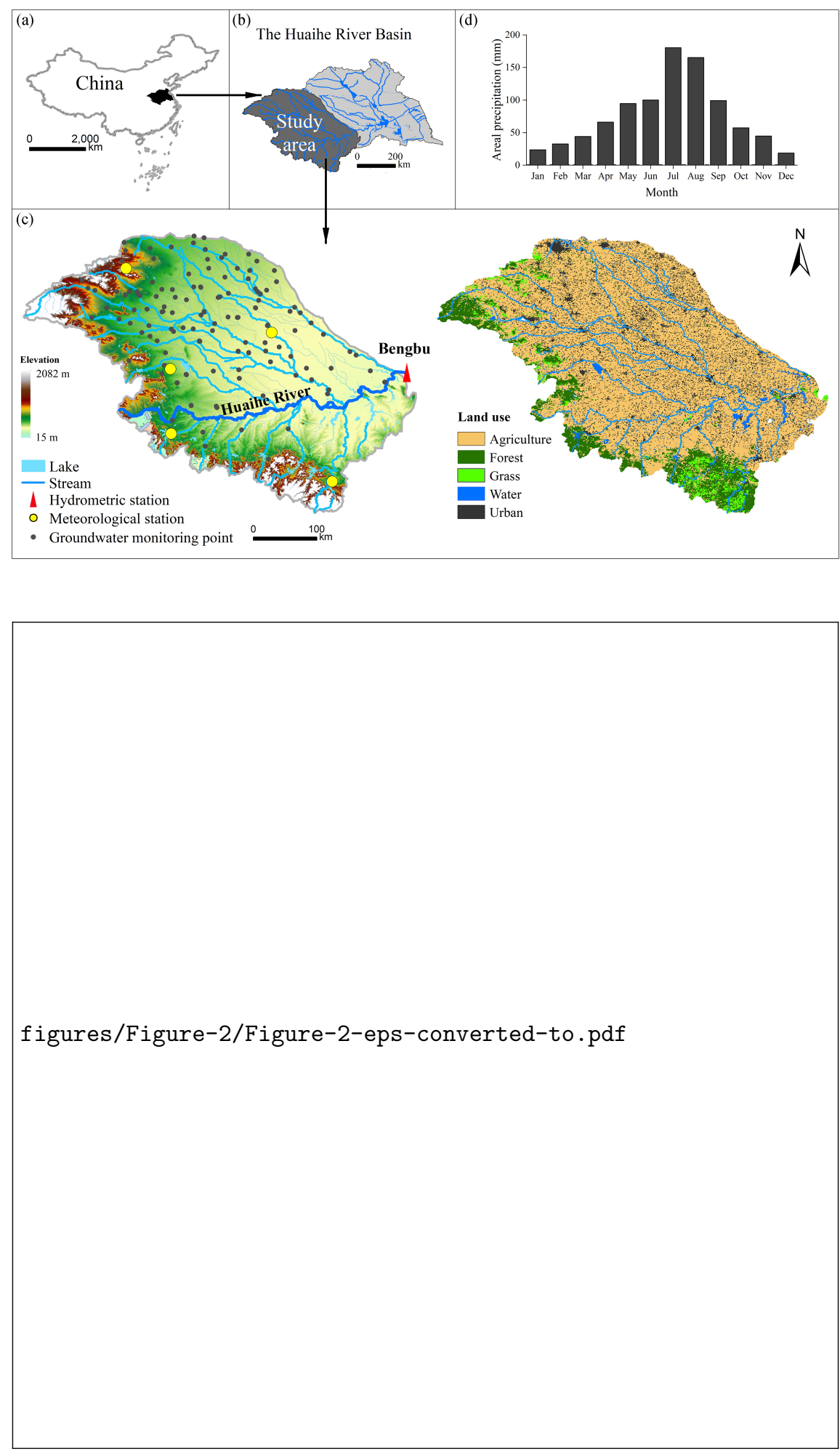
figures/Figure-3/Figure-3-eps-converted-to.pdf 
figures/Figure-4/Figure-4-eps-converted-to.pdf 
figures/Figure-5/Figure-5-eps-converted-to.pdf 
figures/Figure-6/Figure-6-eps-converted-to.pdf 
figures/Figure-7/Figure-7-eps-converted-to.pdf
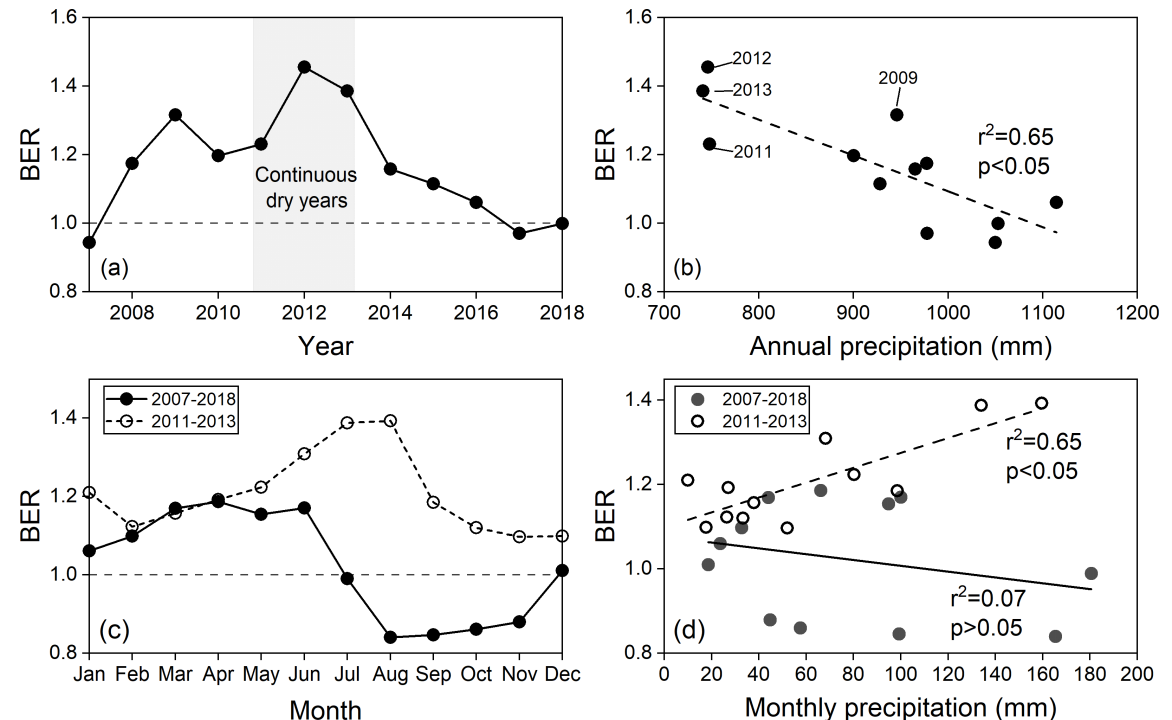